\title{
Analysis of Competency, Organizational Citizenship Behavior (OCB) and Teacher Performance of Vocational High School Taman Karya Madya Teknik Kebumen
}

\author{
Nur Khasanah \\ STIE Putra Bangsa \\ Kebumen, Indonesia \\ nanakhasanah.2105@gmail.com
}

\author{
Umi khasanah \\ STIE Putra Bangsa \\ Kebumen, Indonesia \\ khasanahumi45@gmail.com
}

\author{
Rian Aditya Putra \\ STIE Putra Bangsa \\ Kebumen, Indonesia \\ ryan.aditya124@gmail.com
}

\begin{abstract}
This study aims to analyze competence, organizational citizenship behavior and teacher performance of Vocational High School Taman KaryaMadyaTeknikKebumen. Respondents in this study amounted to 74 people. The analytical method used is descriptive quantitative. The analysis carried out included the research instrument test which consisted of validity and reliability tests, the mean, median and mode tests. The results of the analysis carried out stated that the conditions of competence, OCB and performance of the Vocational High School Taman KaryaMadyaTeknikKebumen teachers were generally considered good because they obtained a mean value of more than 3.01..
\end{abstract}

Keywords: competence, organizational citizenship behavior, performance

\section{INTRODUCTION}

Teachers are positions or professions that require special skills in their main tasks such as educating, teaching, guiding, directing, training, assessing, and evaluating students in early childhood education through formal education, primary and secondary education [1]. Teachers have very important roles, especially as learning managers, administrators, advisors, innovators, creativity advocates, emancipators, evaluators, culminators, models and role models, so that there are so many teacher roles, making the teacher have to be able to carry this burden. In addition, teachers have various tasks and implement them in the form of dedication. Teachers are able to train and build existing skills in themselves to provide diverse knowledge to their students, in other words, teachers are superior human resources. Quality resources, among others, are addressed to high performance and productivity. An organization tries to create satisfactory employee performance for the organization. Every organization will try to develop and improve the performance of its employees to achieve the goals of the organization. Especially in the scope of the school, an organization will strive to have a competent educator workforce, organizational citizenship behavior, and qualified performance in their field.

According to [2]competence is a fundamental factor possessed by someone who has more abilities which makes him different from someone who has average or mediocre abilities. In a school organization, it is required to have more abilities so that teachers are required to have qualified competencies.

According to [3] argues that competence can be described as the ability to carry out a task, role or task, the ability to integrate knowledge, skills, attitudes, and personal values, and the ability to build knowledge and skills. which is based on experience and learning done. This of course makes the teacher combine personal, scientific, technological, social, and spiritual abilities as a whole which is useful to form a teacher competence.

Teachers do not only carry out their duties based on their jobdeskbut can do work outside their responsibilities, such as cooperating, helping each other out, actively participating in organizational activities, providing advice to the organization and contributing more to the organization. These things are a positive behavior from all members of the organization.

According to [4]defines organizational citizenship behavior (OCB) as a discretionary behavior, not directly or explicitly recognized by the normal requirements of work, but in aggregate it can improve the effective functioning of the organization. The importance of building organizational citizenship behavior (OCB) in an organization, especially among teachers of Vocational High School Taman KaryaMadyaTeknikKebumen to increase tolerance and help attitudes among colleagues.

Seeing the importance of organizational citizenship behavior (OCB) in organizations school, which has a positive effect, especially in the scope of the organization, where each member's behavior has a sense of mutual tolerance and is willing to help each other between colleagues when they need help. This is of course a performance behavior that will contribute to an individual that exceeds the demands of a role in the workplace which will have a positive influence or effect on performance.

Teacher performance is the answer to the success or failure of an organization in achieving the stated organizational goals. Performance is a condition that must be known by certain parties to determine the level of achievement of the results of an organization's vision and mission. This is to achieve more productive teacher performance, of course, teachers must have high ability and motivation to work. In this case, the teacher must play an 
active role in setting, supporting, and implementing the plans, processes, and determining organizational goals that have been implemented. This can be achieved if the human resources that are owned are functioning more effectively and efficiently.

Previous research was conducted by[5], with the title competency analysis, organizational citizenship behavior (OCB) and study performance on savings and loan employees in Kebumen sub-district, Kebumen Regency using research methods with quantitative descriptive analysis. The results showed evidence that the competence, OCB and performance of KSP employees in Kebumen District were included in the good category.

The difference between previous research and current research is that it lies in the research subject, previous research took employees of savings and loan cooperatives in Kebumen District, while current research on teachers of Vocational High School Taman KaryaMadya, Kebumen technique.

Based on the above background, the authors are interested in conducting research with the title "Analysis Of Competency, Organizational Citizenship Behavior (OCB), and Teacher Performance of Vocational High SchoolTaman KaryaMadyaTeknikKebumen".

\section{LITERATURE REVIEW}

\section{A. Competence}

According to[2] the notion of competence is a fundamental factor possessed by someone who has more abilities, which makes him different from someone who has average or mediocre abilities. Competency variables in this study are limited to indicators according to [6]namely: Pedagogical Competence, Personality Competence, Social Competence, Professional Competence.

\section{B. Organizational Citizenship Behavior $(O C B)$}

According to [4]the notion of organizational citizenship behavior (OCB) is part of organizational behavior. The personality basis for organizational citizenship behavior (OCB) reflects the characteristics of employees who are cooperative, helpful, caring and serious. Meanwhile, the basic attitude indicates that employees are involved in organizational citizenship behavior (OCB) to reciprocate organizational actions. The variable organizational citizenship behavior (OCB) in this study is limited to indicators according to [7]. Altruism, Conscientiousness, Sprotmanship, Courtesy, Civie Virtue.

\section{Performance}

According to [8]the definition of performance is the result achieved by a person in carrying out his duties on skills, efforts and opportunities. Based on the above explanation, performance is a result achieved by a person in carrying out tasks based on skills, experience, and seriousness and time according to predetermined standards and criteria. Performance variables in this study are limited to indicators according to [9], namely: Understanding of the main tasks, innovation, work speed, work accuracy, cooperation.

\section{RESEARCH MODEL}

\section{A. Sample and Population}

The population in this study is a teacher at Vocational High SchoolTaman KaryaMadyaTeknikKebumen totaling 107 people. The samples taken in this study were teachers and students at Vocational High School Taman
KaryaMadyaTeknikKebumen. The sample in this study were 72 respondents.

\section{B. Data Collection Method The}

Data used are primary data. Data collection was carried out using a questionnaire.

\section{Data Analysis Technique}

Statistical analysis is a method of data analysis using numbers obtained fromprocessing datathrough appropriate formulas. The analysis used includes the validity and reliability test, mean (mean), middle value (median), and the most frequently occurring value (mode). Then to find out the criterion level the mean value of each variable is divided into 4 categories, namely the lowest value (very bad), then bad, then good, and the highest value (very good).

\section{Result AND Discussion}

\section{A. Validity and Reliability Results The validity}

Testtest was carried out to test whether the questions/statements used were valid or not. Question items are said to be valid if $r$ count is greater than $r$ table [10]. Because only 74 questionnaires were analyzed, the $r$ table in this study was 0.2257 . Based on the analysis that has been done, it can be stated that all the questions used to measure competency variables, Organizational Citizenship Behavior and Performance are declared valid. The output of the validity test results can be seen in the attachment tables 1,2 and 3 .

Table 1. Hasil Uji Validitas Variabel Kompetensi

\begin{tabular}{lllll}
\hline No & r tabel & r hit & Sig & Keteragan \\
\hline 1 & 0,2257 & 0,609 & 0,000 & Valid \\
2 & 0,2257 & 0,611 & 0,000 & Valid \\
3 & 0,2257 & 0,751 & 0,000 & Valid \\
4 & 0,2257 & 0,764 & 0,000 & Valid \\
5 & 0,2257 & 0,456 & 0,000 & Valid \\
6 & 0,2257 & 0,698 & 0,000 & Valid \\
7 & 0,2257 & 0,688 & 0,000 & Valid \\
8 & 0,2257 & 0,797 & 0,000 & Valid \\
9 & 0,2257 & 0,720 & 0,000 & Valid \\
10 & 0,2257 & 0,703 & 0,000 & Valid \\
11 & 0,2257 & 0,720 & 0,000 & Valid \\
12 & 0,2257 & 0,803 & 0,000 & Valid \\
13 & 0,2257 & 0,531 & 0,000 & Valid \\
14 & 0,2257 & 0,708 & 0,000 & Valid \\
15 & 0,2257 & 0,652 & 0,000 & Valid \\
\hline
\end{tabular}

Sumber: data primer diolah, 2020

Table 2. Hasil Uji Validitas Variabel $O C B$

\begin{tabular}{lllll}
\hline No & r tabel & r hit & Sig & Keterangan \\
\hline 1 & 0,2257 & 0,729 & 0,000 & Valid \\
2 & 0,2257 & 0,828 & 0,000 & Valid \\
3 & 0,2257 & 0,750 & 0,000 & Valid \\
4 & 0,2257 & 0,826 & 0,000 & Valid \\
5 & 0,2257 & 0,801 & 0,000 & Valid \\
\hline
\end{tabular}

Sumber: data primer diolah, 2020

Table 3. Hasil Uji Validitas Variabel Kinerja.

\begin{tabular}{lllll}
\hline No & $\mathrm{r}$ tabel & $\mathrm{r}$ hitung & Sig & Keterangan \\
\hline 1 & 0,2257 & 0,795 & 0,000 & Valid \\
2 & 0,2257 & 0,731 & 0,000 & Valid \\
3 & 0,2257 & 0,743 & 0,000 & Valid \\
4 & 0,2257 & 0,781 & 0,000 & Valid \\
5 & 0,2257 & 0,764 & 0,000 & Valid \\
\hline
\end{tabular}

Sumber: data primer diolah, 2020 
The reliability test is used to determine whether the statement items used in the study can be used from time to time or not. Questionnaire statement items are said to be reliable if thevalue is Cronbach alpha $>0.60$ [11]. Based on the analysis that has been done, it can be concluded that all statement items used to measure variables can be said to be reliable because theacquisition is Cronbach alpha more than 0.60 . This means that the questions and statements used can be used to measure variables over time. The table of reliability test results is attached.

Table 4 Uji Reliabilitas Kuesioner

\begin{tabular}{llll}
\hline Variabel & $\alpha$ minimal & Perolehan $\alpha$ & Keterangan \\
\hline Kompetensi & 0,60 & 0,920 & Reliabel \\
OCB & 0,60 & 0,841 & Reliabel \\
Kinerja & 0,60 & 0,816 & Reliabel \\
\hline
\end{tabular}

Sumber: Data Prımer Diolah, 2020

\section{B. Analysis Results Mean, Median, Mode}

Mean is the average value of the answers given by respondents. Median is the middle value. Mode is the value that most often appears [12].

1. Competency Analysis

a. The first question "I understand the characteristics of students" obtained mode 3 and a mean of 3.2703 included in the good category. This shows that the teachers of Vocational High School Taman KaryaMadyaTeknikKebumen understand the students well.

b. The second question "I designed learning, including understanding the foundation of education for the benefit of learning activities" obtained mode 3 and a mean of 3.2838 included in the good category. This shows that the teachers of Vocational High School Taman KaryaMadyaTeknikKebumen are able to design learning materials and understand the foundation of education well.

c. The third question "I provide educational learning activities" obtained mode 3 and a mean of 3,5000 is included in the good category.

This shows that the teachers ofVocational High SchoolTaman KaryaMadyaTeknikKebumen provide sufficient educational learning activities for their students.

d. The fourth statement "I did an assessment and evaluation in learning activities" obtained mode 3 and a mean of 3.3784 included in the good category. This shows that the teachers of Vocational High School Taman KaryaMadyaTeknikKebumen are able to carry out assessments and evaluations in learning activities well.

e. The fifth question "I am able to develop the potential of students" obtained mode 3 and a mean of 3.1892 included in the good category. This shows that the teachers of Vocational High SchoolTaman KaryaMadyaTeknikKebumen are able to develop the potential of students well.

f. The sixth question "I act in accordance with legal and social norms well and have a sense of pride in being a teacher" is obtained mode 3 and a mean of 3.4054 is in the good category. This shows that the teachers of Vocational High School Taman KaryaMadyaTeknikKebumen have acted according to legal and social norms and feel quite proud to be teachers. g. The seventh question "I show a mature person and instill a high work ethic of responsibility" obtained by mode 3 and a mean of 3.4324 which is included in the good category. This shows that the teachers of Vocational High School Taman KaryaMadyaTeknikKebumen have been able to show maturity and are able to instill a high work ethic and responsibility.

h. The eighth question "I present an action based on the benefit of students, schools, and society" obtained mode 3 and a mean of 3.4054 is in the good category. This shows that the teachers of Vocational High SchoolTaman KaryaMadyaTeknikKebumen have been able to show actions that are beneficial to students, schools and society as well.

i. The ninth question "I have a good behavior that has a positive effect on students and has abehavior" obtained mode 3 and a mean of respectable 3.3649 is included in the good category. This shows that the teachers of Vocational High School Taman KaryaMadyaTeknikKebumen have been able to show good behavior, have a positive influence on students and are respected.

j. The tenth question "I act in accordance with religious norms and have a behavior that is emulated by students" obtained mode 3 and a mean of 3.3919 is included in the good category. This shows that the teachers ofVocational High SchoolTaman KaryaMadyaTeknikKebumen have acted in accordance with religious norms and are being followed by students well.

$\mathrm{k}$. The eleventh question "I am able to communicate effectively with students" obtained mode 3 and a mean of 3.3784 is in the good category. This shows that the teachers of Vocational High School Taman KaryaMadyaTeknikKebumen have been able to communicate effectively with students well.

1. The twelfth question "I am able to communicate and get along effectively with fellow teachers and educators" obtained mode 3 and a mean of 3.3919 which is included in the good category. This shows that the teachers of Vocational High SchoolTaman KaryaMadyaTeknikKebumen have been able to communicate effectively with fellow teachers and educators well.

m. The thirteenth question "I am able to communicate effectively with the parents of students and the community" obtained mode 3 and a mean of 3.2162 is included in the good category. This shows that the teachers of Vocational High SchoolTaman KaryaMadyaTeknikKebumen have been able to communicate effectively with parents and the community well.

n. The fourteenth question "I am able to understand the teaching materials in the curriculum according to the subject being taught" obtained mode 3 and a mean of 3.3919 which is included in the good category. This shows that the teachers of Vocational High School Taman KaryaMadyaTeknikKebumen have been able to understand the teaching materials in the curriculum according to the subjects that are well managed.

o. The fifteenth question "I am able to understand broadly and deeply about the material being taught" obtained mode 3 and a mean of 3.2568 which is included in the good category. This 
shows that the teachers of Vocational High SchoolTaman KaryaMadyaTeknikKebumen have been able to understand the material broadly and deeply about the material being taught.

2. Analysis Organizational Citizenship Behavior (OCB)

a. The first question "I am trying to help a colleague who is having difficulties in the situation at hand" is obtained mode 3 and a mean of 3.3649 is included in the good category. This shows that the teachers of Vocational High SchoolTaman KaryaMadyaTeknikKebumen are trying to properly help colleagues who are experiencing difficulties in the situation they are facing.

b. The second question "I always try to show the expected behavior of the institution where I work in accordance with the existing rules" obtained mode 3 and a mean of 3.2973 is in the good category. This shows that the teachers of Vocational High SchoolTaman KaryaMadyaTeknikKebumen try to show well the behavior expected of the workplace institutions in accordance with existing regulations.

c. The third question "I always tolerate less than ideal conditions in the organization without raising objections" obtained mode 3 and a mean of 3.0946 is in the good category. This shows that the teachers of Vocational High SchoolTaman KaryaMadyaTeknikKebumen try to tolerate less than ideal conditions in the organization without raising ojections.

d. The fourth question "I always try to maintain good relations with my colleagues to avoid interpersonal problems" is obtained mode 3 and a mean of 3.3378 is in the good category. This shows that the teachers of Vocational High SchoolTaman KaryaMadyaTeknikKebumen try to maintain good relations with colleagues to avoid interpersonal problems.

e. The fifth question "I always try to identify responsibilitiesin the organization" obtained mode 3 and a mean of 3.3378 is in the good category. This shows that the teacher of Vocational High School Taman KaryaMadyaTeknikKebumen is trying to identify responsibilities in the organization.

\section{Performance Analysis}

a. The first question "I understand the main task I have" isobtained mode 3 and a mean of 3.5541 is in the good category. This shows that the teachers of Vocational High School Taman KaryaMadyaTeknikKebumenhave understood well the main tasks they have.

b. The second question "I always have positive innovationsfor teaching and learning activities" obtained mode 3 and the mean of 3.4324 is in the good category. This shows that the teachers of Vocational High SchoolTaman KaryaMadyaTeknikKebumen have good positive innovations for teaching and learning activities.

c. The third question "I am able to carry out the task at a work speed that matches my ability" obtained mode 3 and the mean of 3.3108 is included in the good category. This shows that the teachers of Vocational High School Taman KaryaMadyaTeknikKebumen have been able to carry out tasks at work speeds that match their work abilities. d. The fourth question "I am able to work carefully in every job I do" obtained mode 3 and a mean of 3.2973 is in the good category. This shows that the teachers of Vocational High School Taman KaryaMadyaTeknikKebumen have been able to work carefully in every job.

e. The fifth question "I am able to respect the opinions of other people" obtained mode 3 and a mean of 3.4459 is in the good category. This shows that the teachers of Vocational High School Taman KaryaMadyaTeknikKebumen have been able to respect the opinions of others.

\section{Discussion}

\section{Discussion of Competency Variables}

The results of the questionnaire on indicator number 1 indicate that the teachers of Vocational High School Taman KaryaMadyaTeknikKebumen understand students well, this is indicated by a mean of 3.2703 . The results of the questionnaire on indicator number 2 show that the teachers of Vocational High SchoolTaman KaryaMadyaTeknikKebumen are able to design learning materials and understand the foundation of education well, this is indicated by a mean of 3.2838. The results of the questionnaire on indicator number 3 show that the teachers of Vocational High School Taman KaryaMadyaTeknikKebumen provide sufficient educational learning activities for their students, this is indicated by a mean of 3.5000 . The results of the questionnaire on indicator number 4 indicate that the teachers of Vocational High SchoolTaman KaryaMadyaTeknikKebumen are able to carry out assessments and evaluations in learning activities well, this is indicated by a mean of 3.3784 . The results of the questionnaire on indicator number 5 show that the teacher of Vocational High SchoolTaman KaryaMadyaTeknikKebumen is able to develop the potential of students well, this is shown by a mean of 3.1892 .

The results of the analysis that have been carried out show the mean personality competency dimension of 17,0000. Personality competence consists of 5 indicators. The results of the questionnaire on indicator number 6 show that the teachers of Vocational High SchoolTaman KaryaMadyaTeknikKebumen have acted in accordance with legal and social norms and feel quite proud to be teachers, this is shown by a mean of 3.4054. The results of the questionnaire on indicator number 7 show that the teachers of Vocational High SchoolTaman KaryaMadyaTeknikKebumen have been able to show maturity and are able to instill a high work ethic and responsibility, this is shown by a mean of 3.4324. The results of the questionnaire on indicator number 8 show that the teacher of Vocational High SchoolTaman KaryaMadyaTeknikKebumen have been able to show actions that are beneficial to students, schoolsand society well, this is shown a mean of 3.4054. The results of the questionnaire on indicator number 9 show that the teachers of Vocational High SchoolTaman KaryaMadyaTeknikKebumen have been able to show good behavior, have a positive influence on students and are respected, this is indicated by a mean of 3.3649. The results of the questionnaire on indicator number 10 show that the teachers of Vocational High School Taman KaryaMadyaTeknikKebumen have acted in accordance with religious norms and are followed by students well, this is indicated by a mean of 3.3919 . 
The results of the analysis that have been done show the mean dimension of social competence of 9,9865. Social competence consists of 3 indicators. The results of the questionnaire on indicator number 11 show that the teachers of Vocational High SchoolTaman KaryaMadyaTeknikKebumen have been able to communicate effectively with students well, this is indicated by a mean of 3.3784 . The results of the questionnaire on indicator number 12 show that the teachers of Vocational High School Taman KaryaMadyaTeknikKebumen have been able to communicate effectively with fellow teachers and teaching staff well, this is shown by a mean of 3.3919 . The results of the questionnaire on indicator number 13 show that the teachers of Vocational High School Taman KaryaMadyaTeknikKebumen have been able to communicate effectively with students' parents and the community well, this is indicated by a mean of 3.2162 .

The results of the analysis that have been done show the mean dimension of professional competence of 6.6486. Professional competence consists of 2 indicators. The results of the questionnaire on indicator number 14 show that the teachers of Vocational High School Taman KaryaMadyaTeknikKebumen have been able to understand the teaching material in the curriculum according to the subjects that are well, this is shown by a mean of managed3.3919. The results of the questionnaire on indicator number 15 show that the teachers of Vocational High School Taman KaryaMadyaTeknikKebumen have been able to understand the material broadly and deeply about the material being taught, this is shown by a mean of 3.2568 .

Table 5 Mean, Median, Modus VariabelKompetensi

\begin{tabular}{|c|c|c|c|c|c|c|}
\hline $\begin{array}{c}\text { Dime } \\
\text { nsi }\end{array}$ & Butir & Mean & Median & Modus & $\begin{array}{c}\text { Kateg } \\
\text { ori }\end{array}$ & $\begin{array}{c}\text { Mean } \\
\text { dimensi }\end{array}$ \\
\hline Komp & KP1 & 3.2703 & 3.0000 & 3.00 & Good & 16.6216 \\
\hline etensi & KP 2 & 3.2838 & 3.0000 & 3.00 & Good & \\
\hline Pedag & KP 3 & 3.5000 & 3.5000 & 3.00 & Good & \\
\hline \multirow[t]{2}{*}{ ogik } & KP 4 & 3.3784 & 3.0000 & 3.00 & Good & \\
\hline & KP 5 & 3.1892 & 3.0000 & 3.00 & Good & \\
\hline Komp & KK 6 & 3.4054 & 3.0000 & 3.00 & Good & 17.0000 \\
\hline etensi & KK 7 & 3.4324 & 3.0000 & 3.00 & Good & \\
\hline Kepri & KK 8 & 3.4054 & 3.0000 & 3.00 & Good & \\
\hline badia & KK 9 & 3.3649 & 3.0000 & 3.00 & Good & \\
\hline $\mathrm{n}$ & $\begin{array}{c}\text { KK } \\
10\end{array}$ & 3.3919 & 3.0000 & 3.00 & Good & \\
\hline $\begin{array}{l}\text { Komp } \\
\text { etensi }\end{array}$ & $\begin{array}{c}\mathrm{KS} \\
11\end{array}$ & 3.3784 & 3.0000 & 3.00 & Good & 9.9865 \\
\hline \multirow[t]{2}{*}{ Sosial } & $\begin{array}{c}\mathrm{KS} \\
12\end{array}$ & 3.3919 & 3.0000 & 3.00 & Good & \\
\hline & $\begin{array}{c}\text { KS } \\
13\end{array}$ & 3.2162 & 3.0000 & 3.00 & Good & \\
\hline $\begin{array}{l}\text { Komp } \\
\text { etensi }\end{array}$ & $\begin{array}{c}\text { KP } \\
14\end{array}$ & 3.3919 & 3.0000 & 3.00 & Good & 6.6486 \\
\hline $\begin{array}{c}\text { Profes } \\
\text { ional }\end{array}$ & KP15 & 3.2568 & 3.0000 & 3.00 & Good & \\
\hline
\end{tabular}

Sumber: Data Primer Diolah, 2020

\section{Discussion of Variable Organizational Citizenship Behavior \\ (OCB)}

The results of the questionnaire on indicator number 1 OCB show that the teachers of Vocational High SchoolTaman KaryaMadyaTeknikKebumen try to help their colleagues who are experiencing difficulties in the situation at hand, this is shown as a mean of 3.3649 The results of the questionnaire on indicator number $2 \mathrm{OCB}$ show that the teachers of Vocational High School Taman KaryaMadyaTeknikKebumen try to show well the behavior expected of the workplace institutions in accordance with the existing rules, this is shown a mean of 3.2973. The results of the questionnaire on indicator number 3 OCB show that the teachers of Vocational High SchoolTaman KaryaMadyaTeknikKebumen try to tolerate less than ideal conditions in the organization without raising objections, this is shown to be a mean of 3.0946. The results of the questionnaire on indicator number 4 OCB show that the teachers of Vocational High School Taman KaryaMadyaTeknikKebumen try to maintain good relations with colleagues to avoid interpersonal problems, this is indicated by a mean of 3.3378. The results of the questionnaire on indicator number 5 OCB show that the teachers of Vocational High School Taman KaryaMadyaTeknikKebumen are trying to identify responsibilities in the organization, this is indicated by a mean of 3.3378 .

Table 6 Mean, Median, Modus VariabelOCB

\begin{tabular}{lcccc}
\hline Butir & Mean & Median & Modus & Kategori \\
\hline 1 & 3.3649 & 3.0000 & 3.00 & Good \\
2 & 3.2973 & 3.0000 & 3.00 & Good \\
3 & 3.0946 & 3.0000 & 3.00 & Good \\
4 & 3.3378 & 3.0000 & 3.00 & Good \\
5 & 3.3378 & 3.0000 & 3.00 & Good \\
\hline
\end{tabular}

Sumber: Data Primer Diolah, 2020

3. Discussion of Performance Variables

The results of the questionnaire on indicator number 1 of performance show that the teachers of Vocational High School Taman KaryaMadyaTeknikKebumen have understood well the main tasks they have, this is indicated by a mean of 3.5541. The results of the questionnaire on indicator number 2 of performance show that the teachers of Vocational High School Taman KaryaMadyaTeknikKebumen have good positive innovations for teaching and learning activities, this is indicated by a mean of 3.4324. The results of the questionnaire on the performance indicator number 3 show that the teachers of Vocational High School Taman KaryaMadyaTeknikKebumen have been able to carry out tasks at work speeds that are in accordance with their work abilities, this is shown by a mean of 3.3108 The results of the questionnaire on the performance indicator number 4 show that the teachers of Vocational High School Taman KaryaMadyaTeknikKebumen have been able to work carefully in every job, this is indicated by a mean of 3.2973. The results of the questionnaire on the performance indicator number 5 show that the teachers of Vocational High School Taman KaryaMadyaTeknikKebumen have been able to respect the opinions of others, this is indicated by the mean of 3.4459 .

Table 7 Mean, Median, Modus VariabelKinerja

\begin{tabular}{ccccc}
\hline Butirpernyataan & Mean & Median & Modus & Kategori \\
\hline Kinerja 1 & 3.5541 & 4.0000 & 4.00 & Good \\
Kinerja 2 & 3.4324 & 3.0000 & 3.00 & Good \\
Kinerja 3 & 3.3108 & 3.0000 & 3.00 & Good
\end{tabular}




$\begin{array}{lllll}\text { Kinerja 4 } & 3.2973 & 3.0000 & 3.00 & \text { Good } \\ \text { Kinerja 5 } & 3.4459 & 3.0000 & 3.00 & \text { Good }\end{array}$

Sumber: Data Primer Diolah, 2020

\section{CONCLUSION}

Based on the analysis that has been done, it can be concluded that kompetence of Vocational High School Taman KaryaMadyaTeknikKebumen Teachers are generally good (mean competency variable 50.2568). The dimension that has the highest value is personality competence, which is 17,000 , while the lowest is the dimension of professional competence, which is 6,6486

Organization citizenship behavior Theteachers of Vocational High School Taman KaryaMadyaTeknikKebumen are generally good (mean OCB variable is 16,432). The indicator that has the highest value is altruism, which is 3.3649 . While the lowest is thedimension, sportmanshipwhich is 3.0946.

Teacherperformance of Vocational High School Taman KaryaMadyaTeknikKebumen is generally good (mean performance variable is 17.0405). The indicator that has the highest value is quality, namely 3.5541 . While the lowest was understanding, which was 3,2973.

\section{Implications}

Based on the research conclusions that have been previously presented, the implications of this study are as follows:

\section{Competence}

Competencies held by Vocational High School Taman KaryaMadyaTeknikKebumen Teachers are generally good. The teacher's ability to develop the potential of students is quite good (mean $=3.5000)$. However, the ability to carry out educational learning activities is still relatively low (mean = 3.1892), so that training and development for employees is still very much needed by employees.

2. Organizational Citizenship Behavior (OCB) Organizational Citizenship Behavior performed by teachers is quite good. The teacher tries to help colleagues who have difficulty in the situation at hand is quite good (mean $=3.3649$ ), this can make employees not be overwhelmed in completing their work. However, the behavior of tolerating less than ideal conditions in the organization without raising objections is still not good (mean = 3.0946). Therefore it is important for teachers and management to pay more attention to matters related to time management.

\section{Performance}

In general, the performance produced by the Vocational High School Taman KaryaMadyaTeknikKebumen teachers is quite good. This can be seen from the understanding of the main tasks that the teacher has with the company is quite good (mean $=3.5541)$ However, the accuracy of the teacher's work still has to be improved because the mean value that is owned is only 3.2973. Therefore, schools must improve teacher work competence and must really pay attention to standard operating procedures that must be adhered to by teachers in completing their work so that the work produced has good quality and always increases from time to time.

\section{Suggestions}

Based on the research that has been done, the researcherprovides the following suggestions:

1. For Vocational High School Taman KaryaMadyaTeknikKebumen.

In order for an increase in teacher performance, the management ofVocational High School Taman KaryaMadyaTeknikKebumen Teachers should conduct regular training for all teachers so that the competence possessed by the teacher has increased. In addition, it is important for the Principal to ensure that all teachers work in accordance with established standard operating procedures so that their work processes run more effectively and efficiently.

2. For the next research.

In order for an increase in management science, further research is expected to further improve the quality of research. In this study only limited to the school scale. Future studies are expected to be investigated on a larger scale. In addition to the expanded scale, further research can develop more interesting research concepts to do.

\section{REFERENCES}

[1] Imran, "Pembinaan Guru Di Indonesia," Jakarta: Pustaka Jaya., 2010.

[2] A. P. Mangkunegara, "Evaluasi Kinerja Sumber Daya Manusia," Edisi Pert., Bandung: PT. Remaja Rosdakarya., 2005.

[3] R. A. Roe, "Trust Implications for Performance and Efectiveness.," Eur. J., 2001.

[4] F. Luthans, "Perilaku Organisasi," Edisi 10., Yogyakarta: Andi Offset, 2006.

[5] M. Irfatah, "Analisis Kompetensi, Organizational Citizenship Behavior (OCB), Dan Kinerja Studi pada Karyawan Koperasi Simpan Pinjam se Kecamatan Kebumen, Kabupaten Kebumen. Tesis Magister Manajemen," Program Magister (S2) UTY, 2019.

[6] T. Priatna, Nanang dan Sukamto, "Pengembangan Profesi Guru," Bandung: Remaja Rosdakarya, 2013.

[7] T. Purnamie, "Peranan Organizational Citizenship Behavior," Bandung: Mitra Wacana Media, 2014.

[8] M. S. Hasibuan, "Manajemen Sumber Daya Manusia," Jakarta: Penerbit Bumi Aksara, 2002.

[9] M. dan K. T. R. L. Fadel, "Reinventing Government (Pengalaman Dari Daerah)," Jakarta: PT. Elex Media Komputindo., 2009.

[10] Sugiyono, "Metode Penelitian Kuantitatif Kualitatif dan R\&D," Bandung: ALFABETA, 2008.

[11] I. Ghozali, "Aplikasi Analisis Multivariate dengan program SPSS," Semarang: UNDIP, 2009.

[12] Sugiyono, "Metode Penelitian Kuantitatif Kualitatif dan R\&D," Bandung: ALFABETA, 2016. 